\title{
Postfeminist Micro-Politics in Shobha De's Novel Second Thoughts
}

\author{
Dr. Aishwarya M
}

M.A., M.Phil., PhD.

Assistant Professor and HOD

Department of English (SF)

PSGR Krishnammal College for Women,

Coimbatore -641004, Tamil Nadu, India

ash7arya14@gmail.com

DOI: https://doi.org/10.24113/ijellh.v9i4.10987

\begin{abstract}
The novel Second Thoughts deals with the story of a young middle class Bengali girl who marries a Bombay based foreign returned Bengali Boy. The story depicts the disillusionment of a married woman and an explosive tale of love and betrayal that exposes the hollowness of human relationship especially within arranged marriages. This chapter deals with the concept of Micro-Politics which is a significant dogma of postfeminism. Micro-Politics believes that there has been drastic change in the position of women in basic social relationships, within the families, workplace and other public spheres. Postfeministic notion of micro-politics is intended to provide insight into the complicated nexus of relationship and also to rethink this same concept in terms of postfeminism.
\end{abstract}

Keywords: Disillusionment - Relationship - Postfeminism - Micro-Politics - Women Patriarchal Attitude - Women's Duty- Restriction - Domestic Sphere. 


\section{Postfeminist Micro-Politics in ShobhaDe's novel Second Thoughts}

Shobha De is a well-known personality in Indian media and journalism and a famous writer in the literary world. She has been long associated with the contemporary world of glamour and Indian cinema. Shobha De was the editor of popular magazines such as Stardust, Society, and Celebrity. She was also actively involved in scriptwriting for various TV soap operas including India's famous soap daily titled Swabhimaan. At present, she is a freelance writer and columnist for several newspapers like Times of India and various other magazines. Shobha De has a number of fiction and non-fiction to her credit.

Women hold multiple positions in their life as they balances between domestic and professional responsibilities. Patricia Mann formulated a theory to describe the condition of an individual who is actively participating with the norms prescribed by the society and terms it as "Micro-Politics" (Mann160). According to Mann a fundamental transformation has occurred at the late twentieth century which was a direct result of the enfranchisement of women and their "unmooring from patriarchal relations" (Genz 172). Patricia Mann believes that there has been drastic change in the position of women regarding their basic social relationships, within their family, workplace and other public spheres. Mann explains the concept of micro-politics thus:

...we may be expected to change jobs, careers, marriages, and geographical venues with the same resignation or optimism as we switch channels. We may be described, without undue exaggeration, as operating within a tangle of motivations, responsibilities, rewards, and forms of recognition unmoored from traditional male and female, public and private identities. (115)

Mann's notion of micro-politics is intended to provide insight into the complicated nexus of human relationship in this postmodern era of drastic change in cultural and social norms. 
Second Thoughts is the story of Maya, a young and attractive middle class woman who accepts an arranged marriage with Ranjan. She indulges in an extra marital relationship with Nikhil, though her digression from her marriage is short lived. This incident happens because her husband Ranjan exhibits emotional and sexual indifferences towards her. Alka Saxena opines;

Second Thoughts is a realistic representation of the psyche of the traditional Indian men and women. Although they claim to be the proved products of the twenty-first century, but deep down they still cherish and nourish the age-old norms and traditions. In that much familiar pattern, the status of men and women has hardly undergone any change. (261)

The story of Maya can been seen as a perfect example of postfeminist micro-politics because Maya represents the identity of young contemporary women who "engage in a resistant fashion with the choices they have available at the micro-level of everyday life" (Budgeon 7).

Bombay is considered as the land of opportunity and most Indians migrate to Bombay to fulfil their dreams; for them, it is a world of fantasy. People in the small towns have great fascination towards the life style of Bombay. They settle down in Bombay in order to lead a life that they reverie of. Being a Bengali, Maya steps into Bombay with the same delusion of living in a metropolis. She leads her life in a world of fantasy and fascination in Bombay. Maya fantasises about romance and marriage and enters married life with great expectation.

When a woman gets ready for marriage she consciously hopes and believes that all her ideas and hopes of finding love, companionship and all pleasures of life gets fulfilled within the marriage. When she fails to achieve this marital bliss, she starts developing detachment with her partner, it leads to dislocation and displacement of their relationship. Maya and Ranjan's marital life is punctuated all along by matrimonial indifference. Maya 
understands that her husband never has the capacity to appreciate her aspirations. She is also sexually frustrated because of her husband's impotency and this leads to alienation from her husband. Maya realises that there is no emotional and sexual compatibility between her and Ranjan.

On a sultry May evening in Bombay Maya meets Ranjan, her future husband. She arrives from Calcutta earlier in the day to meet her in-laws-to-be. Maya's family members travel from Calcutta to meet the groom and family to make the marriage proposal work in a positive direction. Initially Maya protests the idea of the sudden arrangements made by her family regarding her marriage. When she protests against an arranged marriage, her mother argues: "Ranjan is quite a catch. Who knows, by the time we get to Bombay, some other lucky girl might have grabbed him" (ST 3). Then Maya replies that it is not as if he were the last bachelor on earth. Maya is confident that she will surely find a good match for herself. Maya likes her skin, a warm, rich golden brown, like sunlight dancing on the Hooghly that offset her gleaming black hair and large, dark eyes to advantage. However, she abides by her mother's wishes and decides to go ahead with the marriage proposal decided by her family.

Maya and her family members start for Malik's residence a good hour before the appointed time. Maya feels happy after seeing the house; she quickly looks around and finds the house very neat and clean. She feels at home because the house was similar looking to her own house in terms of appearance. While Maya sits down on a stuffed sofa, Mrs. Malik begins to talk high about her son Ranjan and his past life in America. Her mother Chitra, Prodipda uncle and Maya nod a bit that they are in perfect harmony with the sentiment.

Maya is surprised and disappointed by Ranjan's lack of common courtesy and comments about it to her mother on their way home. Ranjan declares that he is earning well; and it is the women's duty to run a good home. It is clear that Ranjan has patriarchal notions of domination. 
Maya in Second Thoughts suffers due to her financial dependence on Ranjan. Similarly, traditional Indian women like Maya's mother have to request their husbands for money even for their daily needs. Financial security is the basis for women's emancipation. (Neb. Feminist Stance 178)

In this globalized world, the status of woman is consolidated due to the proliferation of job opportunities which makes her achieve financial freedom liberating her from the monetary dependence on men. Even before marriage Ranjan curbs and controls the financial independence of Maya.

It is quite natural that women in their young age dwell in a world of fantasy, having their own dreams about life, love, romance and marriage. Maya says that she feels very happy being in Bombay. Taking this as a positive sign Chitra confirms that her daughter's marriage is fixed with Ranjan. Chitra is sure that Maya will fall passionately in love with the boy. At last Bombay would definitely become her eventual home thus Maya's dream of residing in Bombay would come true.

After marriage Ranjan and Maya shift to an apartment in Bombay. Ranjan gets busy with his work leaving Maya all alone in the house. One day Nikhil Verma, her neighbour asks whether she will be able to come out of the house. He is different from his family members unlike his mother, Pushpa who invites Maya for coffee the day after she moves into the building. When she introduces her son Nikhil, Maya could evidently spot the difference between the mother and her son. At that moment, Nikhil asks twenty rupees to pay for the cab. When his mother hesitates, Maya gives him the required money; in return, he thanks her by addressing her as aunty. She feels like an 'elder' to him though he may be just five or six years younger than her. One day while purchasing, the salesman on seeing Nikhil pass by makes a casual comment that Nikhil is a boy who gets mixed up with girls like Nalini Mehta and other girls in the locality. After hearing this incident, Maya feels a sudden and 
unreasonable jealousy that immobilizes her for a while. Maya feels strange and tries to control her emotions and reminds herself that she is a married woman.

It is a bitter experience for any woman if her husband is passive to her all the time. One day, Ranjan comes home early in the evening complaining of headache. He sighs like a man on his deathbed and nods in slow motion. Dr. Goal examines him efficiently while saying soothing words of confidence. Maya tries to take care of her husband but she soon realizes if she shows affection, it makes him uncomfortable. So she decides to take a back seat and allows the doctor to do his job. In the same way Maya is hurt when Ranjan objects to hear wearing flowers in her hair. The first time she comes home with a flower winding in her hair, Ranjan smells the air suspiciously. Because according to him women with loose character wear flowers or apply kajal and use perfume to tempt other men. Thus he is very much hostile even to the small desires of Maya.

Some men with patriarchal attitude always believe that women's duty is only restricted to the domestic sphere. One day, Maya asks Ranjan to go out together on weekends; he replies that life is not a picnic and as a married woman Maya has to be responsible. She urges him that she can find a job as she has a degree in textile designing. He explodes saying: "In our families, the only sort of work ladies do is social work. Our relatives will criticize us if you suddenly take up a job" (ST 29). Still, some men are unable to accept the independence of women.

Shobha De captures the middle class psyche by exposing various facets of Ranjan - his attitude to hold on tight to the purse strings so as to control his woman, his lectures on wifely duties, his complete control even on the use of the air-conditioner .... (Saxena262)

The silence in the house becomes unbearable for Maya. So she decides to take a step towards mending her relationship by starting a conversation with her husband. Foolishly, she 
decides to make small talk to break the silence. Ranjan gets furious and throws down a halfeaten slice of bread by accusing her of bad behaviour because of chatting to neighbourhood women. She answers angrily that she has nobody else to talk to all day. In reply, he tells that there is music, television and activities like cleaning the house to pass the time. It is the passive attitude of Ranjan which Maya cannot bear. That night, she creeps into the bed as silently as possible but he seems to be in deep sleep. She lies awake marvelling how to induce sleep. She tries resorting to pleasantly contorted memories of college days but nothing worked out untill Nikhil comes into her dream. It is an instance that makes her think of Nikhil as an alternative to satiate her emotional and physical needs.

Nikhil exploits Maya who is frustrated in her married life in order to fulfil his carnal pleasures. Nikhil's uninvited presence makes her develop a sort of infatuation towards him. One day Nikhil rings her door bell at noon and he repeatedly asks her whether he can call her 'didi'. She answers that he should call her by her name or whatever he feels comfortable with. The image of Nikhil starts giving a strange relaxation to her mind. She stops trying to resist the melting ache that is emanating through her stiff body. In fact, she laughs so much that her body moves with unexpected and unfamiliar glee. She is half-afraid her secret will disturb Ranjan's sleep but it does not.

Maya receives long letters from her mother at regular intervals. The content of the letters are long advices on how to be a good and obedient wife. As a young girl, Maya was sometimes allowed by her mother into her room while she dresses after her quick bath. Her parents have always slept in different room. Insolently, she teases her mother: "what is the issue, Ma? Tell me. Why don't you and Baba sleep on the same bed? And why can't I sleep between the two of you?" (ST 37). She smacks on the head saying lamely that Maya will understand on her own about it later. It is not the time to ask her mother so that she decides to ask her father instead. He answers that their taste is different from hers. 
A year after their marriage, Maya tells Ranjan that they ought to have a serious talk about their relationship. Ranjan with a defensive look announces that wives should realize that when a man comes home dead tired he craves for a little peace in the house. This drives Maya desperate as she is unable to solve her problem nor break her marital bond. Maya is always an unwelcomed person inside their bedroom. She never feels wanted or invited in the bedroom as it remains Ranjan's room, where as the kitchen is an area that belongs exclusively to her. This incident is an instance to highlight male chauvinism and indifference, which make women to bear the inhibition imposed by the society for years. Late one evening, while she is struggling to keep mustard seeds in hot oil, she heard the doorbell. It is Nikhil, who tells that his mother has sent the world's best dahi-wada to her. She takes the dish from his hand thankfully as Ranjan loves dahi-wadas. However she is not sure what to talk to Nikhil. She feels he is very smart for her. She craves for the company of an affectionate person. Whenever Ranjan insults her, she guiltily washes her face watching her image in the mirror over the wash basin and dreams of Nikhil and a small secret smile dances around her mouth with mirth.

One day, as Maya lazily watches at her collection of saris, her fingers pinpoint at a parrot green one with a narrow black woven border. Gradually, a second thought develops in her mind. She recalls Nikhil's comment a few weeks ago. He says: "You look like a beautiful garden today" (ST 45). When she goes back to the bathroom, she notices Ranjan's reflection in the mirror from the back and he was watching her attentively. "Maya's tragedy is that she is treated like a figure made of a 'alabaster' and not of 'flesh and blood' before marriage by her mother and after marriage by her husband" (Barche 275). It shows the sheer indifference of Ranjan towards Maya's sexual urges though she may be his spouse.

When Maya asks, Ranjan tells her in a broken voice that it is difficult for him to maintain a relationship with any woman. She enquires whether he felt comfortable with his 
girlfriend while he was in America. Even after a year their marriage was not consummated but Maya never hates Ranjan. In facts now and then she is attracted towards his charm. As a matter of fact she believes that there is something attractive about his smile, his thick dark hair and large eyes.

Ranjan feels guilty to discuss his failures with the six girls he has tried to make love to; it is not at all a sexual gambit. When the first year of their marriage is over, her life becomes very much of a routine. Once in a while, she would receive sweet phone calls from Ranjan's women colleges issuing invitations to various sari sales in the city. But he gets suspicious when she referred Vimla Rangani's call. One day she complained that she has to make some friends in Bombay. Ranjan replies if she needs company, she can call his mother as she has lived there for over twenty - five years. He also says that a wife's duty is to stay at home and discharge responsibilities and she should learn such values from his mother. Ranjan worships his mother very much and in return she adores him.

One day out of curiosity Maya asks Prodipmama about her father-in-law, Amartya Malik but gets a bleak answer. Sometime ago, she comes across an old photograph of Amartya Malik with his son Ranjan and enquires lightly about their relationship. Then Ranjan's irritable expression indicates that his father is no more.

Maya starts registering her impressions of Bombay in a shiny green diary presented by her mother, which many of the entries are related to Nihkil who is good-looking having average height, athletic build, tanned skin, nice hands, nice eyes, nice smile which makes him sound like a college girl's dream boy. In fact, his presence brings a slight difference to her dull life.

Ranjan fails as a husband who never realises his wife's desires. Maya often entices to pick up the phone and speak to her mother or an old school friend called, Aarti in Calcutta. Her mother and Maya have a strange relationship, as they are bored of each other most of the 
time. She cannot talk to her mother and share her grievances as she is sure that her mother will not understand her. And she does not have the phone numbers of her college friend. She feels trapped in Ranjan's house, and this feeling suffocates her.

As Maya was performing her daily chores her main focus was on the thoughts of Nikhil. She was dreaming about him as she was mechanically doing her work. She misses him for days except once as he runs through the June rain and jumps into a waiting car. It is around seven one evening, while she is in the kitchen preparing Ranjan's tea tray, she hears the doorbell ring, it is Nikhil who surprises her. He requests her to play something on her cassette recorder. He tells her to listen to the fourth song on side B and then he departs. She is shocked to see Ranjan and she stands puzzled staring at him. But Ranjan does not notice the tape in her hand which she tries to hide.

Nikhil notices her depression and decides to write a sad, sad song about a lonely lady. She appeases herself that at least there is something to look forward to at the end of the weekend. It gets very difficult for Maya to maintain equilibrium in life. Maya's prolonged waiting and anxiety are planned at around 10.30 the next morning. She hears a smart knock at the door, assuming that it was Nikhil she rushes to the door. It is Nikhil, dressed in dirty Jeans and a white KhadiKurta, gestures with his hands to ask if her husband were at home. He nods as her eyes communicate the fear she was experiencing. He raises the left hand and waves to meet her on Monday. She does not dare react but raises her voice unnaturally not to come again. But Nikhil becomes his usual blur as she quickly shuts the door on him. That morning, the bathroom door is indeed open, so that Ranjan enquires who that person is. Her voice trembles when she answers that he is young Verma boy. Then Ranjan comes from the bathroom asking why she has described him as 'young'. Ranjan also asks whether he is a regular visitor in that case. She starts feeling anxious and frightened. Ranjan curses the 
Verma boy as a loafer and of bad character. He also suggests that young married women should not invite loafers into their home, when the husband is away.

Ranjan does not raise the topic of Nikhil again that weekend hoping that she would change her ways soon. Ranjan narrates a story of how his colleague's neighbour's wife was deceived by strangers. While Maya looks out of her window one afternoon, she notices Nikhil there. Nikhil invites her to have some 'bhelpuri'. Initially she refuses him to eat it because Ranjan does not like it. But when Nikhil mocks at her asking whether her husband prohibits her from eating bhelpuri, she feels very much embarrassed.

When the predicament of woman is unnoticed by her husband, she finds consolation outside. Maya listens to Nikhil's tape on Monday, when Ranjan leaves the house. His exit always generates a sense of exhilaration not because she does not want him around, but she feels free in his absence. Ranjan is a nervous person who can rarely find things even if they happen to be under his nose. She hears the tape, it's a poem written by Nikhil about a lonely lady which Maya hears for around twenty times in a row. Ranjan rarely phones from his office but one day he dials her saying that she has to wear yellow sari, which was given to her by his mother because his mother was visiting them that evening.

Maya finds a note from Nikhil which was lying under the door which was inscribed, 'Liked it'. She admires his handwriting and once again dreams of Nikhil. He is careful enough to avoid names. She crushes the piece of paper angrily and then releases her fist to see what she has done. She sits down heavily, she hears the phone ringing outside but defiantly she decides to let it go on ringing. Finally she picks the call and to her surprise it was Nikhil. She keeps quiet for a moment, puzzling how he got her number. One day the post man refuses to hand over a letter to her over some issue at that time Nikhil enters the house and warns the post man to give it to Maya. When he is about to leave, she touches his arm reluctantly saying that she loves his song. 
Maya experiences her first Bombay monsoon and she enjoys it. Though it is depressing, she actually surrenders to the monsoon's many moods. But the rains put Ranjan into a bad mood. Ranjan is due for a promotion later in the year which is obviously weighing on his mind. Recently, he acquires a new boss, Tom, an American who was just twenty-nine. In this context, she starts giving references about his job from what she reads from 'Time' magazine. He raises his voice impatiently: "Maya- it's better for women not to make immature, ignorant comments on subjects they know nothing about” (ST 115).

Ranjan restricts Maya's freedom by stopping her from expressing her opinions. Then she suggests mildly that he should invite his boss home for dinner to which he agrees. Perhaps, he feels slightly more confident about inviting his American boss home. He knows that his Calcutta wife is not entirely ignorant about things around the world. It makes her wonder why he has not picked a Bengali girl from Bombay. When she asks about it, he replies that these Bombay Bengalis do not safeguard their cultural identity. Then she suggests whether they should invite Mathurs to dinner. He refuses saying that those people from Uttar Pradesh are aggressive and shameless. He continues that Maya has to take some time to get adapted to Bombay.

Some men do not hesitate to make use of their wives' charm to climb the ladder of their career. When the doorbell rings at precisely 8.30 p.m., Ranjan straightens his shoulders to invite his boss, Tom Becker. Ranjan has a peculiar way of talking to and greeting foreigners in English. Her mother-in-law tells her that he is very good at English, both spoken and written. But Maya tries to correct him gently once or twice. Tom looks at her appreciatively commenting that she wears a nice lovely coloured Bengali sari. Next, he stares at a beautifully crafted set of brass rice bowls which he praises. She feels secretly pleased as they were presented by her paternal uncle as a wedding gift. At the dinner table, he tells 
Maya that he likes Indian food as he is sick of those five star curries served in hotels. The dinner that follows is dominated by Ranjan's office matters.

From time to time, Tom catches her eye and smiles. She is not sure whether or not to return his smile, since Ranjan may later on accuse her of disloyality. After dinner, Tom follows her into the kitchen praising that the dinner is excellent. In reply, she whispers he is a liar. In response, he tells that he wants to relish the real dinner during his next visit. After Tom leaves, Ranjan asks her whether Tom liked her dinner. She answers that Tom likes it very much and he wants to visit their home again. Surprisingly Ranjan is very much delighted with the news instead of getting suspicious of Maya.

Maya says that she has decided to join pottery class as she has a lot of leisure time. Ranjan answers: "Housewives don't have extra time-there so much to be done around the home. Take Ma's example. She is busy round the clock" (ST 139). He continues saying that those so-called classes are often nothing but recruitment places for prostitution as Bombay is the country's prime place for it. As she listens to Ranjan, her mind reels off in a crazy direction, in the background, she would hear Niki Marx, a Television anchor's reports. Ranjan seems to be very much excited to pay attention to Niki by commenting on her clothes and hair style. Maya likes Niki too and often fantasizes about her challenging life. Maya suddenly remembers that during her college years her ambition was to become a journalist. In her paternal home reading newspaper was consider as a serious affair. Her father read the 'Ananda Bazar Patrika' and her mother, 'The Telegraph'. But all her ambition remains buried after her marriage.

The first time Ranjan goes out of town on business, Maya wishes to take the next train back to Calcutta as she is horrified at the thought of being alone in her Bombay flat. When she expresses her fear, he assures that it is a pretty safe building and Pushpa as well as her neighbours can take care of her. He is elated at the prospect of staying in a five star hotel on a 
ten day trip. One afternoon, when she lies on her bed flipping channels, she watches an enthralling image on the screen in which a man and woman are swimming like playful dolphins in blue waters. She finds her cheeks wet with tears, when she can figure out herself with the woman in the orange bikini and Nikhil, as her underwater companion. Her occasional cravings include an unending sadness in her, as she knows that such desires will never materialize either with Ranjan or with Nikhil.

When Ranjan is away for a trip, Maya experiences a strange blankness. She thinks of her mother as she stares at the luminous star. Then the world becomes a vacuum for her. The out-station phone facility of the house is locked by Ranjan every day before leaving the house, because he fears the increase in telephone bills. This act clearly which indicates his rigid attitude in giving economic freedom to her. He gives a thousand rupees for her saying not to spend more than fifty rupees a day. He continues saying that only if any emergency occurs she can contact his mother. She sits around dully, having a feeling of relief in his absence. She feels guilty of not missing her husband as it is supposed to be. She feels: "Was I really such an uncaring, cold and selfish person? Why was I not longing for my husband's return like a loyal, loving wife?" (ST 163). Maya feels that though Ranjan has his follies, he is not an evil man.

Freedom is permitted in a very restricted manner; it is the ancient story of sacrifice and adjustment that a woman is destined to. Sooner or later she learns to adjust, as there is no other alternative, if she needs to live a respectful life. Maya, too, accepts to remain enveloped in the loneliness and sadness. On second thoughts, she learns to survive the sultriness of not only Bombay, but also of her marriage. (Saxena 271) 
Though Indian men and women begin adopting the changing trends in the society recently, they still feel obliged to follow traditional customs which we have being following for centuries.

Nikhil once again visits the house. He enters the house with all rights and sits down on the sofa. She really wants to keep away from him and leave her alone to bask in her misery. He senses her nervousness and shuts the door firmly. She asks him foolishly that her husband's absence does not give him the right to move into her house. He begins to get on her nerves by his presence in her flat. She tells him that she doesn't approve of his presence in her home. He replies: "I'm feeling awful today. So are you. I need cheering up. So do you. Now, off you go-cold coffees for two. Got it?"(ST 167). Silently, she goes into the kitchen and moves mechanically, like a programmed robot to prepare coffee for both.

Nikhil asks her to come for a ride with him to overcome the dullness. In response, she goes into her bedroom and changes into a fresh sari. She is firm to get out of the house anyway and explore Bombay. The heat is far less oppressive riding on the saddle of Nikhil's motorbike. After parking his bike, he and Maya stride up to the famous garden built over a massive tank. Surprisingly, she is neither weighed down with guilt nor does she want to think about the consequences. But this is the outing she had longed forever since the day she has arrived and felt Bombay as hers.

Nikhil was silent on the way home; when they reach their building he asks Maya whether she wants to go anywhere else. She jumps off the bike about half a kilometer from her house. She marches back home with a heavy heart. When she enters the compound, the watchman enquires about her outing and then she stares coldly at the man. At that moment, a woman called Leena Mehta from the ground floor comes to her flat making her feel bored with her conversation. She wants to be alone, to relive the morning and to recreate the 
invaluable moments, Nikhil and she has shared recently. She feels that she has taken a big risk during the outing with Nikhil. She likes having Nikhil around. Ningthoujam states:

Second Thoughts is the only De novel which sketches the life of the higher middle class and in the character of Maya presents woman who apparently conforms to the norms of the society but secretly breaks them when she finds them unjust and unacceptable. (99)

Maya is the replica of so many Indian middle class women in the urban context, where they rebel against the male chauvinism silently. Patriarchy confines them to their home without allowing them to accomplish their desires. Ranjan phones from Delhi that night asking if she was okay, but she murmurs some unclear sounds saying that she is really frightened. She does not know how she will be able to survive the night. As her mind is filled with fear, her head is crammed with all types of absurd images. She knows there is no point in forcing herself to sleep, as she feels very much tense and dreaded. She reaches for a small note pad that she used to keep on her bed side and begins writing a letter to Nikhil.

Maya wants to convey to Nikhil in that letter how she feels during the time they spend together, she feels bad as she betrays Ranjan. When she gets married to Ranjan, everybody is happy and a little jealous as she is leaving for Bombay. She still believes that she is very lucky to have become Mrs. Ranjan Malik. She confesses it is wrong for a married woman to go out with a man especially in her husband's absence. If Nikhil invites her to come out with him again, she probably would do it with guilt. Though she comments all these things, she is unsure whether to give the letter to Nikhil or not. She feels tired and falls into a light sleep.

We see particularly with regard to projecting the psyche of an Indian married woman who is caught and crushed between the nature- culture wheels on the one hand, and pulled apart by the centrifugal acts of Ranjan, her husband and those of centripetal of Nikhil, her lover, on the other. (Barche 280) 
The predicament of Indian middle class woman reflects the conflict of female psyche, when she is oppressed in the hands of her husband who never allow her to enjoy freedom all through her life.

Maya's relationship with Nikhil invigorates her dull life beyond measure. When the doorbell rings at exactly at ten' o clock the next day, Maya literary jumps out of bed and rushes to the door. It is Nikhil, who asks her to come with him. But she refuses to his proposal and he abruptly leaves the place. She expects him to persuade her. She is mesmerized about Nikhil's life outside that building. Nikhil considers Maya and Ranjan as uninteresting and uncool. In this respect she feels that two uncool people stick together in unholy matrimony.

Ranjan makes a phone call to her and Maya is relieved to hear his voice but he does not pay attention to her suffering. Instead, he mentions crisply about office papers, keys and his investments and then keeps the receiver down. She sticks to the receiver for a few seconds, for she wants him to talk to her and enquire about her. She feels tears springing up in her eyes and she hastily brushes them away with an impatient, angry gesture: "Why not? Didn't husbands share pleasant nothings with their wives?" (ST 207). One day she makes a point to call her uncle and vent out her problems, but in the mid way she stops. When he encourages saying more, Maya complains that Ranjan is passive to her advances. Prodip mama says: "Ah, but men-husbands-rarely phone their wives just for a chat. Jamaibabu is no exception as that lovely-dovey talk only takes place during courtship. After marriage, everything changes" (ST 208). She is not convinced at all but has no desire to continue the conversation. She does not tell her parents about Ranjan's presence in Calcutta. When compared to her father, Maya realised how men are receptive towards their wife's family members. 
Maya feels that she misses her mother's food. But Ranjan has already specified, "Men get used to eating a certain kind of food" (ST 122). She finds herself remembering her mother at each meal though her mother was not a good cook. Her own wedding feast was not met with her mother's approval, since the arrangements have been left to Prodipmama and his dull wife. Her parents had sanctioned a petty budget for that.

Nikhil's shadowy figure rolling on and off his battered bike continues to dominate Maya's thoughts. Ranjan's absence affects her in a strange way when her slow, dull daily routine life becomes more boring. She thinks she will feel free of various duties like cooking the moment he has left for the airport. When Maya assures that her house is clean, Ranjan gets angry and asks her not to behave like Pushpa. She asks him why he always verbally abuses Pushpa. He bursts out saying "She is going to ruin her husband's career, I tell you. Mark my words. And she'll finish off that loafer son of hers. I hate woman like that. They have no culture, no feelings" (ST 228). Maya is stunned at Ranjan's strong and negative opinions on everybody.

Maya does not realize till that point how strongly he feels about Nikhil and his mother. She wishes to defend 'that boy' and explain that he is not bad. Ranjan looks into her face and obviously waits for some type of reaction. She is cautious that her expression remains neutral. She tells him about Nikhil's mother's statement that he is a good student who works hard for a scholarship to study in United States of America. Ranjan shakes his head saying that he was also a good student but he never depended upon his father for money like Nikhil. She feels: "Now I had walked into a potential landmine that would blow up in my face in a moment unless I found some way of diverting it" (ST 230).

Maya is happy at the home coming of Ranjan and she asks cheerfully if she can make Ranjan a cup of coffee. He shakes his head and continues to glare at her. Abruptly, he asks her whether she has been meeting Nikhil by any chance. When she said she hasn't met him, 
he says that he smelt a cigarette smoke in the house and suspected Nikhil was visiting Maya. She says that it was the carpenter, who came to repair the door kept on smoking. She holds her breath, wondering whether Ranjan would accept her lie. Fortunately, he is convinced with that explanation.

On seeing Ranjan's genuine lack of interest in her, Maya sometimes wonders whether he fancies any women. Though they enjoy their physical closeness and the warmth of his body Maya craves for these moments and cherishes them for days afterwards. Only once, at a dull office party, Maya observes Ranjan looking animated while talking to a woman. He shows his fascination for another woman quite openly in her presence. By the same argument, if she says what she does feel for Nikhil, he will also have to acknowledge that she is innocent. She introduces herself to the woman, with whom Ranjan is intimate at the party; she comments that Maya is a Bengali. She asks him why everybody calls her a Bengali at the party; he says that everybody there are from Bombay. She feels tears rolling down in her eyes, which lead to some disturbance between her and Ranjan.

Ranjan returns from his trip in a jubilant mood. Maya decides to go to the airport to greet him, not at all sure whether he would be pleased to see her there. When Ranjan walks up to her briskly, she feels quite silly and awkward. He hands over a sari sent by her mother and she feels disappointed. On the way home, he wants to visit his mother as he has not met her for a long time and asks Maya to go home.

As Maya struggles with Ranjan's small bag outside their building, Nikhil's arm reaches out from behind her and lifts it out of her hand. When he comes in, she says: "How long does it take to make a phone call? I was worried about you. I also thought you were upset with me. Were you?" (ST 249). She requests to Nikhil to wait there, for she wants him to read a letter written by her. At that point, she hears the car driving up; she hurriedly pulls the bag into the house and drags it towards the room. In a hurry, she misses seeing an Iron 
wire lying across the living room floor. Her sandals get entangled in the wire and she falls over Ranjan's bag and is injured. Ranjan sits next to her and presses an icepack on her injured elbow.

They are locked together in a relationship that does not satisfy either of them. Then she feels that he had married her to satisfy his mother and she had married him to get away from Calcutta. PriyaWanjari believes,

...the husband-wife relationship in Second Thoughts is in no way different from the one expressed in the earlier novels. Though all kinds of necessary things for a successful life are available in the family, both husband and wife drift away in different directions. (201)

Maya who was suffering in pain, limps by herself to her room. At that time instead of helping her, Ranjan asks Maya that he is going to inform about her condition to his mother. She replies that she can settle manage her domestic duties by herself. He reprimands that she is passive towards his mother. She says that she is a little scared of her as she is very strict. That night, as she lies beside her husband, she starts thinking about sex. Once or twice, when she raises the subject, he shouts: "Are you that Sex-Starved? Nothing else on your mind? How can sex be so important to anybody, I've never understood" (ST 257). Here Ranjan utterly fails in understanding the physical needs of his wife. He makes her feel so ashamed of herself for possessing such thoughts. She wonders what Ranjan does to satisfy his desires.

Sometimes, Maya thinks she should take the initiative and try her luck with him. That night when she reaches out for him, he objects saying that he needs rest after a hectic tour. She attempts her level best to coax him but fails. She does not want to blame Ranjan as she absurdly coaxes him. D. MuraliManohar points out:

The main reason for Maya to think in this manner is Ranjan's indifference to her emotional and sexual desires. One has to blame Ranjan for his lack of 
understanding about his wife. Ranjan thinks that he is providing everything to his wife. He is providing material things. What about personal care, tenderness, affection, emotional expressions and romantic feelings? That does not mean Nikhil is providing all that. He is only an opportunist exploiting her. (162)

Maya's mother-in-law rarely phones before seven-thirty in the morning so that Maya becomes speechless to hear her voice at six o' clock. Ranjan's voice is afflicted as he knows something is wrong even before his mother can say it. When she asks him what has happened, he explains briefly that his mother has suffered a heart-attack. Ranjan rushes to the hospital. She sits by the window for more than two hours for she has never felt so useless. She feels desolate in her heart saying to herself: "Nobody needed me, absolutely nobody" (ST 295). Maya's parents no longer thought that she belonged to them. "My husband belonged to his mother. It was unlikely that I would bear children who would belong to me. And I didn't have a single true friend to call my own" (ST 266).

At that moment, Maya hears the doorbell ringing, she goes to answer it wearily. She opens the door and turns around to go back into the bedroom without even bothering to check who the caller is. It is Nikhil who greets her and then she around and the sight of the flowers in his hand astonishes her. He walks in declaring how they should celebrate his birthday. He kicks the door shut with the heel of his shoe; he grabs hold of her shoulders and pulls her into his embrace.

Maya feels, "Every bit of me was suddenly alive to the feel of Nikhil's lips, hands, arms, neck, chest, knees and legs. An unknown recklessness started to sweep over me" (ST 268). She can feel him distinctly as she becomes a captive to Nikhil's advances. She has no desire to move, as she wants to taste the sweet mirth in her mind. She wants to lie there for 
the rest of life relishing what had taken place between her and Nikhil. "Maya's frustration and her rebellious nature cannot allow her to take her husband's indifference lying down. Maya decides to seek the fulfilment of her dreams elsewhere, however sinful it might be" (Ningthoujam40).

In order to escape from the sterile conjugal life, she follows her own means to accomplish her dreams. When Maya is involved in a sexual encounter with Nikhil, she forgets her own self. The thought that she her own husband never considers her beautiful fills her with an overwhelming sadness. She hears Ranjan's voice calling out, she rushes to the door and opens it but fails to notice the discarded bouquet. It is the first thing Ranjan spots, when he walks angrily past her. Before she can ask him how his mother is, he enquires who had presented the bouquet to her. She replies that they are meant for his mother but he is unconvinced. She starts asking about his idea of bringing his mother home in order to divert his attention she becomes successful. In her newly awakened state, she was dying to meet Nikhil as she craves to share her feelings with him. Maya involves in promiscuity, but never realizes that she has been exploited by another man.

It is observed that women demonstrate much courage to fulfil their desires, when men restrict them by robbing their freedom. The next ten days Maya plays the entirely unused role of full-time nursemaid to her mildly ailing mother-in-law. Between her sick-bed duties and routine domestic chores, she does not have a single moment for herself. Each and every action of hers involves Nikhil in some way. She is alive to every aspect of living because she knows she has Nikhil in her life. It is at around eight that night when she is making a chicken soup, Nikhil's mother, Pushpa comes with sweets in her hand announcing that Nikhil's marriage is arranged and he has got a seat in Rochester University. Maya stands transfixed till Ranjan comes out of the kitchen to inform her that the chicken soup has been burnt. She leans against the refrigerator to steady herself as her body is shaking with disbelief .Then she looks 
at the spilled soup; she knows she will have to make it again from scratch as she has all the time in the world.

JaydipsinhDodia in his article, "Second Thoughts: A Critique"criticizes the institution of marriage in India as:

In Second Thoughts, Shobha De vividly presents an "explosive tale of love and betrayal" at the surface level and the "hollowness and hypocrisy" lurking behind Indian traditional marriages at the deeper level. Thus the novel focuses on the hollowness of Indian marriage. (281)

It is not easy for an Indian woman writer like Shobha De who has explored the reality concealed in Indian marriages by exposing wives' adaptability according to the existing norms, even while being fettered in the clutches of her husband, devoid of freedom all through her life, leads to estrangement in the traditionally enveloped society. 


\section{Works Cited}

Barche, G.D. "Maya: Another eve in Second Thoughts.".The Fiction of Shobha De. Ed. JaydipsinhDodia. New Delhi: Prestige, 2000. 275-280.Print.

Budgeon, Shelley. "Fashion Magazine Advertiding: Constructing Feminity in the "Postfeminist" Era."Gender and Utopia in Advertising: A Critical Reader.Eds Luigi Manca and Alessandra Manca. Lisle, IL: Procopian Press, 1994. 7-10. Print.

De, Shobha.Second Thoughts. New Delhi: Penguin, 1996. Print.

Dodia, Jaydipsinh .The Fiction of Shobha De.New Delhi: Prestige, 2000. 281. Print.

Genz, Stephanie and Benjamin A.Brabon.Postfeminism:Cultural Texts and Theories.Edinburgh: Edinburgh University Press, 2012. 68-172. Print.

Mann, Patricia S. Micro-Politics: Agency in a Postfeminist Era. Minneapolis and London: University of Minnesota Press, 1994. 115-160. Print.

Manohar, D. Murali. "Rejecting the Hegemony': The 1990s." Indian English Women's Fiction: A Study of Marriage, Career and Divorce. New Delhi: Atlantic Publishers \& Distributors (P) Ltd, 2007.131-162. Print.

Neb, Narendra Kumar. "Feminist Stance in ShobhaDe's Novels."Critical Responses to Feminism. Ed. Binod Mishra. New Delhi: Sarup\& Sons, 2006. 161-178.Print.

Ningthoujam, L Sonia.Image of the New Women in the Novels of Shobha De. New Delhi: Prestige, 2006. 13-99. Print.

Saxena, Alka. The New Women of Shobha De. New Delhi: Prestige, 2009. 262-271.Print.

Wanjari, Priya. Contemporary Fiction: An Anthology of Female Writers. New Delhi: Prestige, 2007. 197-201. Print. 